\title{
ПРОЦЕДУРА БИОВЕЙВЕР КАК ОСНОВА ОЦЕНКИ ВЗАИМОЗАМЕНЯЕМОСТИ ЛЕКАРСТВЕННЫХ ПРЕПАРАТОВ
}

\author{
И.Е. Смехова, Ю.М. Ладутько, О.В. Калинина \\ Кафедра технологии лекарственных форм, ФГБОУ ВО «Санкт-Петербургский \\ государственный химико-фармацевтический университет» Министерства \\ здравоохранения Российской Федерации (ФГБОУ ВО СПХФУ Минздрава России), \\ 197376, Россия, Санкт-Петербург, ул. Профессора Попова, д.14, лит. А.
}

DOI:10.19163/MedChemRussia2021-2021-194Ｅ-mail:Irina.Smekhova@pharminnotech.com

Биовейвер (biowaiver) - это процедура, в соответствии с которой определение взаимозаменяемости и регистрация генериков проводятся на основании их биофармацевтических свойств (по биофармацевтической системе классификации (БКС)) и эквивалентности in vitro, как альтернатива исследованиям биоэквивалентности in vivo [1].

Регуляторную процедуру биовейвер допускают нормативные документы FDA, BO3, Агентства по фармацевтической продукции и медицинским приборам, МЗ Украины, Европейского медицинского Агентства, Канады и др.

В России в настоящее время процедура биовейвер законодательно не регламентируется, а испытания сравнительной кинетики растворения in vitro применяются для оценки эквивалентности разных дозировок одного и того же генерика, и учитываютсяпри регистрации генериков [2]. В 2016 г. данная процедура была принята Решением Совета Евразийской экономической комиссии [3].

Возможность проведения процедуры биовейвер зависит от определенных условий. Это должна быть твердая лекарственная форма немедленного высвобождения системного действия. Действующие вещества должны обладать широким терапевтическим индексом, быть хорошо растворимыми и подвергаться полной или ограниченной абсорбции (I или III класс по БКС). Учитываются характеристики растворения in vitro исследуемого и референтного препаратов, качественный и количественный состав вспомогательных веществ, способных повлиять на биоэквивалентность. Оцениваются также риски при принятии ошибочного решения о применении процедуры биовейвер.

Таким образом, обоснованные данные, полученные in vitro, позволяют избежать проведения исследований биоэквивалентности in vivo.

\section{Литература}

[1] V. Mirsha, U. Gupta, N. K. Jain,Pharmazie. 2010. N65 (3), P. 155-161.

[2]Руководство по экспертизе лекарственных средств ФГБУ «НЦЭСМП» Минздрава России. M, 2013.

[3]Об утверждении Правил проведения исследований биоэквивалентности лекарственных препаратов в рамках Евразийского экономического союза. Решение Совета Евразийской экономической комиссии от 03.11.2016г. №85.

$$
-194-
$$

